\title{
Collaboration and modelling - Tools for integration in the Motueka catchment, New Zealand"
}

\author{
Andrew Fenemor ${ }^{1 *}$, Neil Deans ${ }^{2}$, Tim Davie ${ }^{3}$, Will Allen ${ }^{3}$, John Dymond ${ }^{5}$, Margaret Kilvington ${ }^{3}$, \\ Chris Phillips ${ }^{3}$, Les Basher ${ }^{1}$, Paul Gillespie ${ }^{4}$, Roger Young ${ }^{4}$, Jim Sinner ${ }^{4}$, Garth Harmsworth ${ }^{5}$, \\ Maggie Atkinson ${ }^{1}$ and Rob Smith ${ }^{6}$ \\ ${ }^{1}$ Landcare Research, Private Bag 6, Nelson, New Zealand \\ ${ }^{2}$ Nelson Marlborough Fish \& Game Council, Nelson, New Zealand \\ ${ }^{3}$ Landcare Research, Lincoln, New Zealand \\ ${ }^{4}$ Cawthron Institute, Nelson, New Zealand \\ ${ }^{5}$ Landcare Research, Palmerston North, New Zealand \\ ${ }^{6}$ Tasman District Council, Richmond, Nelson, New Zealand
}

\begin{abstract}
A conceptual model of integrated catchment management (ICM) is presented in which ICM is defined as a process to achieve both ecosystem resilience and community resilience. It requires not only biophysical knowledge developed by hydrologists and other environmental scientists, but an active partnership with catchment communities and stakeholders to break the 'paradigm lock' described by the UNESCO-HELP programme.

This paper reports observations from ICM research in the Motueka HELP demonstration basin in the upper South Island of New Zealand. The Motueka occupies $2170 \mathrm{~km}^{2}$ of land yet the river effects are felt on the seabed more than $50 \mathrm{~km}^{2}$ offshore, so the true 'catchment' is larger. A hydrologically temperate mountainous catchment with horticultural, agricultural, plantation forestry and conservation land uses, the Motueka also hosts an internationally recognised brown trout fishery. Land and water management issues driving ICM research include water allocation conflicts between instream and irrigation water uses, impacts on water quality of runoff from intensifying land uses, catchment impacts on coastal productivity and aquaculture, and how to manage catchment processes in an integrated way that addresses cumulative effects of development.

Collaboration with catchment stakeholders can be viewed as having two primary purposes:

- Building knowledge and commitment of resource users towards sustainable resource management (collaborative learning) - Stakeholder involvement in resource management itself (governance).

Examples are presented of a Collaborative Learning Group on Sediment learning of their differing perspectives on fine sediment impacts, and a Catchment Landcare Group working with scientists to improve water quality in their river. Success factors for water user committees making decisions about water resource management include creating opportunities to communicate and build trust, share scientific knowledge on the issue, and willingness to compromise. Functioning catchment groups have potential to take on delegated governance responsibility for meeting agreed water quality and other community goals. Finally a scenario modelling framework IDEAS (Integrated Dynamic Environmental Assessment System) is presented, in which environmental indicators such as nutrient fluxes are simulated alongside socio-economic indicators such as job numbers and catchment GDP for a range of land and marine use options.
\end{abstract}

Keywords: integrated catchment management (ICM), resilience, HELP, UNESCO, water governance, Landcare, scenario modelling, collaborative learning, water allocation, water user committees, catchment groups, watershed management

\section{Toitu te marae o Tane Toitu te marae o Tangaroa Toitu te iwi \\ If the domain of Tane and Tangaroa are healthy the people will be healthy}

(Proverb from the indigenous Māori of Aotearoa/New Zealand-Tane is god of forests, birds and the fertility of the land; Tangaroa is god of rivers, lakes and oceans)

Revised paper. Originally presented at the symposium 'HELP in Action: Local Solutions to Global Water Problems - Lessons from the South' which was held at the Emperor's Palace, Johannesburg, South Africa from 4 to 9 November 2007.

* To whom all correspondence should be addressed.

푤 +643545 7710; fax: +64 3545 7701; e-mail: fenemora@landcareresearch.co.nz

\section{Scope of paper}

This paper reviews some integrative approaches aimed at better linking environmental research and management (particularly hydrological science) with economic, social and cultural outcomes in the Motueka HELP basin of New Zealand. The examples presented include collaboration methods and an integrative modelling approach called IDEAS (Integrated Dynamic Environmental Assessment System). These are among the research findings from the Motueka basin developed since the 2002 Kalmar HELP symposium (UNESCO HELP symposium, Kalmar Sweden 8-22 August 2002. Towards integrated catchment management: Increasing the dialogue between scientists, policy makers and stakeholders.) (Bowden et al., 2004).

The 2170 km$^{2}$ Motueka catchment in New Zealand's South Island (Fig. 1) is a HELP demonstration basin from a hydrologically temperate zone (Basher (ed.) 2003). The Motueka catch- 


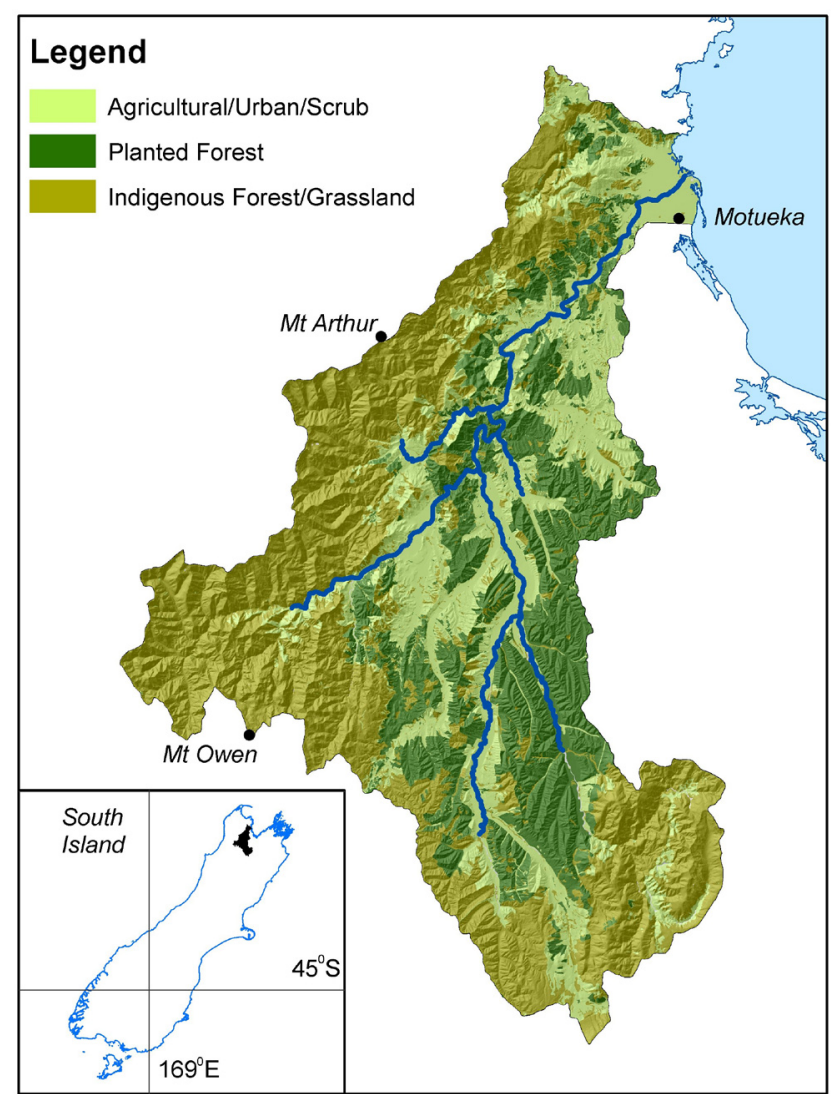

Figure 1

Motueka catchment, South Island, New Zealand

ment is home to New Zealand's integrated catchment management (ICM) research programme (http://icm.landcareresearch. $\underline{\text { co.nz/). }}$.

This is a government-funded research partnership in which researchers, community and sector group stakeholders, and local government work collaboratively on basin-scale resource management issues. This includes catchment impacts on the adjacent coast, in which the seabed influence of the river plume extends more than $50 \mathrm{~km}^{2}$, meaning that effectively the catchment extends beyond the river mouth (Forrest et al., 2007).

\section{Conceptual models for ICM}

We define ICM similarly to integrated water resource management (IWRM) and the principles of the UNESCO-HELP programme - but with more focus on land-water interactions:

Integrated catchment management is a process that recognises the catchment as the appropriate organising unit for understanding and managing ecosystem processes in a context that includes social, economic and political considerations, and guides communities towards an agreed vision of sustainable land and water resource management for their catchment.

Thus ICM is a holistic, transdisciplinary approach to managing the natural resources of a catchment with the people of that place. It is a process rather than an outcome. Figure 2 shows our conceptual model for ICM as a science-based iterative process. Here catchment-scale issues are identified with stakeholders, knowledge about those issues is built through a research and monitoring process, and this leads to action and re-evaluation.

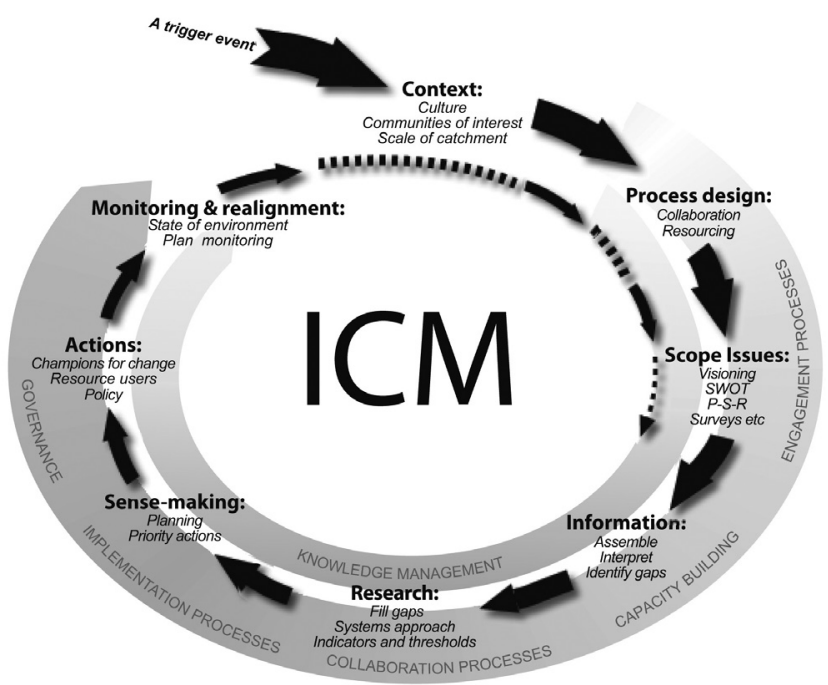

Figure 2

Integrated catchment management (ICM) as a science-based process

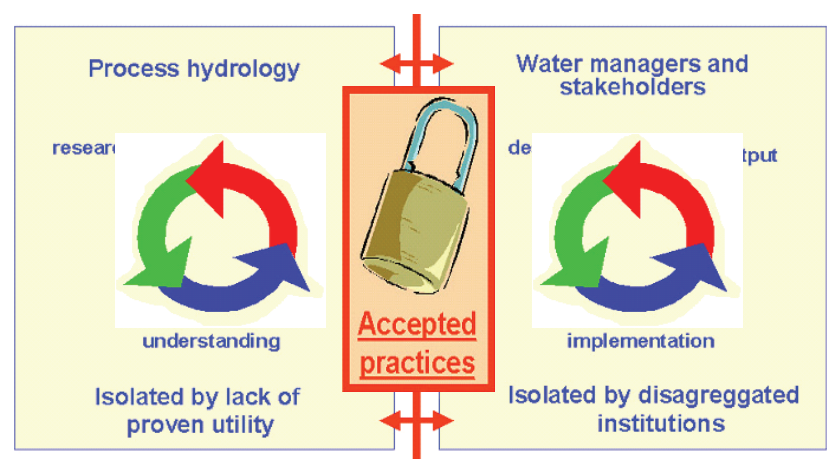

Figure 3

HELP paradigm lock (from Bonell and Askew, 2000)

While this process might suggest a major role for biophysical science such as hydrology, modern catchment management is less of a technological fix involving top-down management and engineering solutions than fifty years ago. Catchment managers still need knowledge about biophysical processes such as water yields, sediment loads and aquatic ecology. But they also need to understand community values and aspirations for their place in the catchment, and engage stakeholders in resource management. These bring in social, cultural and economic (including political) dimensions to management.

So we see modern ICM as having two pillars: biophysical knowledge and social process. Including the social pillar is a way to break the 'paradigm lock' (Fig. 3) described in the HELP programme (Bonell and Askew, 2000) so that scientific expertise and local knowledge work hand-in-hand (Fig 4).

The social process outlined below in Fig. 4 (and applicable also to Fig. 2) focuses on strengthening participation and selfhelp in natural resource management projects. It is a specific approach that emphasises the steps needed to develop the knowledge and action for changing problem situations constructively. These steps consist of familiar processes used in other fields of cooperation, designed around basic management actions. The first of these involves establishing a climate for change with the different parties involved and setting goals and objectives. This is followed by steps that involve searching for information and developing a shared understanding and action plans to address 


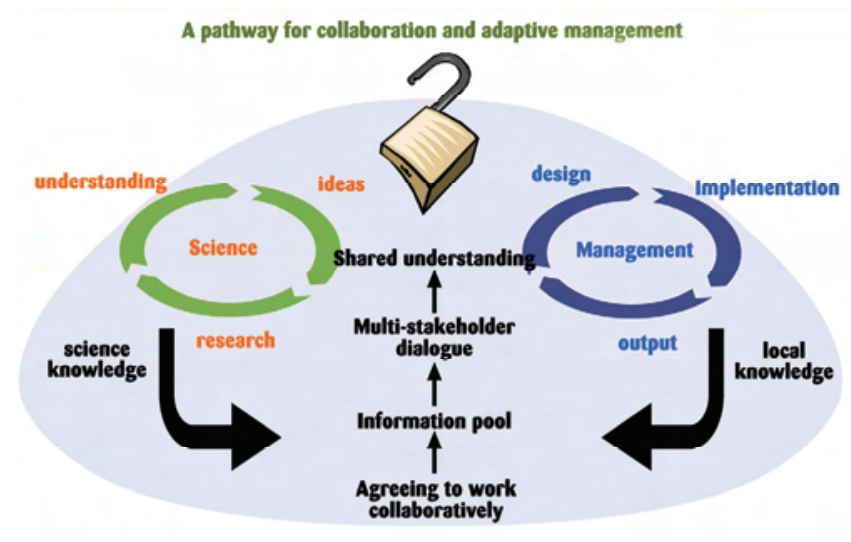

Figure 4

A social process approach to breaking the HELP paradigm lock through collaboration (adapted from Allen and Kilvington, 2005)

the issue. Finally, the circular nature of the process stresses the need to develop feedback loops to maximise the benefits from monitoring and evaluation and to develop a collaborative learning/self-improving environment.

Resilience theory (Gunderson and Holling, 2002) also offers a conceptual model for ICM and for HELP. Based on our two pillars, the objective of ICM is to achieve both ecosystem resilience and community resilience. By understanding and managing biophysical processes and fluxes of natural capital across a catchment, catchment managers identify ways to build ecosystem resilience. Similarly, by mapping and developing community networks and values, and managing our place together, we build community resilience and social capital. This model implies a combination of top-down and bottom-up governance because it is the combination of scientific understanding, institutional structures for resource management, and empowered people living within a catchment which will generate resilient catchment management.

Achieving resilience should not be seen as some sort of optimisation process with a single outcome. Rather resilience is about understanding thresholds for change and about adaptive management (Gunderson and Holling, 2002). Attributes of resilience relevant to ICM include maintaining diversity and ecological variability within the catchment and community; modularity; recognising slowly expressed variables such as the slow response of groundwater quality to land use change; feedback; social capital; innovation; multi-level governance; and accounting for ecosystem services (Walker and Salt, 2006).

\section{Institutional ICM framework for New Zealand}

The institutional setting for catchment management greatly affects its successful implementation. Water management in New Zealand was regionally formalised with the establishment of catchment boards with the Soil Conservation and Rivers Control Act 1941, although its early emphasis was on soil conservation and flood control rather than water resource management. The Water and Soil Conservation Act of 1967 launched a more comprehensive water management regime, introducing the water rights for water allocation and seeking to protect water quality, at least in respect of point source discharges. Catchment Boards in 1967 were also given the task of water management planning as Regional Water Boards.

A further and significant re-organisation of all natural resource management came with the passage of the 1991 Resource Management Act (RMA) which integrated water resource management with that of other natural resources including air, land use and coastal management. Water resource management is primarily the responsibility of regional councils, the successors to catchment and regional water boards. There are 16 regional councils covering NZ. The RMA introduced statutory management planning into water management in an attempt to address cumulative effects on a catchment basis and the consequences of incremental changes on natural resources. The RMA, however, has struggled to deal with water and other resource allocation issues within an 'effects based' management regime. It has proven adequate where water is not short, but is inequitable and rigid as competition for water increases.

By comparison with many countries New Zealand is well endowed with water on a per capita basis, with some very high annual rainfall in some areas. Despite its temperate climate, New Zealand still has many localised areas with seasonal water shortages and areas of high water demand for irrigated horticulture, viticulture, dairy farming and arable cropping.

Within the Tasman District (Tasman District Council being one of the 16 regional councils) lies the Motueka catchment. The Motueka River has a nationally recognised recreational brown trout fishery. Protection of the fishery habitat was sought in 1990 with application by the fishery manager for a statutory water conservation order. This would prescribe river flow and water and river habitat quality standards necessary to sustain the fishery into the future. In negotiating the flow regime in particular, water users and particular irrigators and land owners in the upper Motueka River catchment were concerned that flow protection for the fishery might unduly limit access to water for out-of-stream use.

Prior to the hearings on the conservation order application, the river experienced a major decline in the abundance of brown trout. Explanations for this varied between observers, including floods, fine sediment smothering the river bed, over-harvesting by anglers, water extraction during low flows, and afforestation. These issues touched many in the community, from anglers and the tourist industry, landowners including horticulture, pastoral farming and forestry, and the urban residents of Motueka town. Understanding the relative importance of these different factors influencing the trout fishery became one of the major underlying reasons for the ICM research being undertaken in the Motueka River catchment (Fenemor et al., 2006).

This has provided the opportunity to model catchment futures, with changes in the proportion of different land uses (from dry stock farming to dairy, or farming to forestry, for example). From the outset, a major component in the programme has been maintaining interest in and feedback from the community by way of social research.

\section{ICM process in the Motueka catchment}

So how has the ICM process introduced in Fig. 2 been applied to the Motueka catchment? Reconciling catchment scales with the scales of communities of interest is the first issue. It becomes more difficult the larger the catchment and the less topographically defined the catchment (eg catchments with large deltaic floodplains). The Motueka is distinct topographically (Fig. 1) but has separate upper and lower catchment communities of interest. The nature of the resource management issues also affects the management scale for ICM. While there are specific subcatchment issues such as poor water quality and water shortage for irrigation, these are part of a bigger picture of effects of land use on rivers and then the coast, so a whole catchment basis for ICM is justified for the Motueka. 
Based on meetings across the catchment and a stakeholder survey (Bowden and Wilkinson, 2000), the following major ICM issues were identified as requiring research:

- Water allocation is a significant issue among water users, with tensions between instream flow needs for the trout fishery and consumptive needs of irrigation; there has also been conflict between water allocated for irrigation and the interception of rainfall by forestry development, reducing former levels of river and groundwater recharge. Understanding the dynamics of surface and groundwater hydrology in this seasonally-dry catchment is helping to develop sustainable water allocation policies and rules.

- The impacts of water use and land management practices - especially sediment movement - on the Motueka River and its tributaries, which are a nationally and internationally recognised trout fishery.

- The consequences of the combined impacts of land and river management on coastal aquaculture and fishing industries, which are of national economic importance.

- Cumulative effects of catchment development by an increasing and more diverse population, including increasing tourism and Māori cultural and business opportunities.

Figure 5 shows these as generic themes. A fifth research component is integrative tools and methods across all four themes. While the Motueka ICM/HELP programme aims to be more transdisciplinary than multidisciplinary, Table 1 shows for project management purposes how individual research strands map to the themes of Fig. 5.

This research focuses on integrating knowledge and management at large catchment scale, so the primary audiences for our research are our research partners - Council policy and environmental monitoring staff, and resource users such as the farming, forestry and marine farming sectors.

Returning to the thesis that effective ICM needs to integrate both biophysical understanding and stakeholder participation, the remainder of this paper describes results and observations from our research on collaborative learning and integrative modelling (*asterisked in Table 1). Based on involvement of the two senior authors in various water committees, we also make some observations about design and success factors for such collaborative groups.

\section{Collaborative processes}

Collaboration with stakeholders has at least two dimensions for catchment management:

- Building knowledge and commitment of resource users towards sustainable resource management (collaborative learning)

- Stakeholder involvement in management of land and water resources (governance).

The design of opportunities for collaborative learning is therefore an important facet of ICM. Kilvington and Allen (2007) suggest this design should have the following features:

- Established relationships between science providers and stakeholders that foster trust and agree mutual expectations

- Managed opportunities for multi-party critical reflection on specific problems

- Knowledge repository and retrieval systems that extend information and learning beyond core participants

- Progress review and process adjustment.

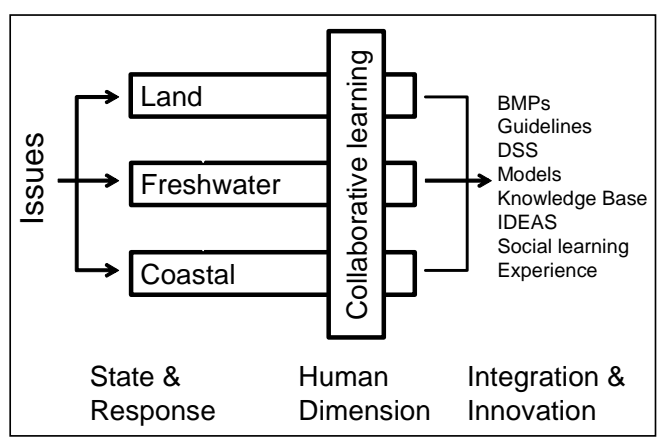

Figure 5

ICM Research Themes and Outputs

\begin{tabular}{|c|c|}
\hline \multicolumn{2}{|r|}{$\begin{array}{c}\text { TABLE } 1 \\
\text { ICM research projects by theme in the } \\
\text { Motueka HELP catchment }\end{array}$} \\
\hline \multirow[t]{4}{*}{ Freshwater } & $\begin{array}{l}\text { Modelling effects of land uses on river water quality } \\
\text { and habitat }\end{array}$ \\
\hline & Trout migration in response to low flows and floods \\
\hline & $\begin{array}{l}\text { Links between Māori cultural and scientific indica- } \\
\text { tors of river health }\end{array}$ \\
\hline & Fish-friendly floodgate design and management \\
\hline \multirow[t]{6}{*}{ Land } & $\begin{array}{l}\text { Faecal bacteria and on-farm actions to minimise } \\
\text { stream contamination }\end{array}$ \\
\hline & $\begin{array}{l}\text { River-aquifer modelling for sustainable water alloca- } \\
\text { tion }\end{array}$ \\
\hline & Land use effects on streamflows and nutrient loads \\
\hline & Riparian restoration methods using native plants \\
\hline & River gravel transport, monitoring and management \\
\hline & $\begin{array}{l}\text { Sediment sources, yields and modelling of its river } \\
\text { and coastal impacts }\end{array}$ \\
\hline \multirow[t]{2}{*}{ Coastal } & $\begin{array}{l}\text { River plume effects on offshore benthos and water } \\
\text { column }\end{array}$ \\
\hline & $\begin{array}{l}\text { Modelling catchment effects offshore for ecosystem } \\
\text { function and aquaculture space allocation }\end{array}$ \\
\hline \multirow{4}{*}{\begin{tabular}{|l|} 
Collaborative \\
learning*
\end{tabular}} & Collaborative learning approaches for ICM \\
\hline & $\begin{array}{l}\text { Building iwi (Māori tribal) capacity and } \\
\text { collaboration for ICM }\end{array}$ \\
\hline & $\begin{array}{l}\text { Enhancing institutional learning by the Council for } \\
\text { ICM }\end{array}$ \\
\hline & Science responsiveness to community needs \\
\hline \multirow[t]{5}{*}{ Integration } & Knowledge management and delivery for ICM \\
\hline & Mediated modelling of catchment futures \\
\hline & $\begin{array}{l}\text { IDEAS - an integrated modelling framework for test- } \\
\text { ing catchment scenarios* }\end{array}$ \\
\hline & Defining ICM as a process \\
\hline & $\begin{array}{l}\text { Improving water allocation and management by link- } \\
\text { ing hydrological sciences and policy }\end{array}$ \\
\hline
\end{tabular}

A range of collaborative learning methods have been trialled in the Motueka catchment, including:

- The Community Reference Group, a group of residents acting as a sounding board for research direction and uptake of results

- A Collaborative Learning Group on Sediment, described below

- Hui (discussions) and powhiri (formal welcomes at the Māori meeting house) to develop an iwi (tribal) GIS and a river monitoring protocol

- Sector workshops, including one on alternative water allocation options, and one on the science behind river gravel management 
- Water User Committees set up by Tasman District Council, also described below

- Watershed Talk, a dialogue process exploring ideas about care and responsibility for the environment, which built on the participatory success of the earlier art-science collaboration Travelling River

- A catchment landowners' group (Landcare group) in the Sherry subcatchment who are implementing farm management practices which are improving river water quality

- An annual general meeting of researchers, council staff and catchment stakeholders

- The Motueka Toolbook, an interactive CD-Rom distilling catchment information to answer stakeholder questions

- An on-line discussion group Confluens for some 70 people within the ICM research programme

- Our ICM research website http://icm.landcareresearch. co.nzl

- A mediated/companion modelling process for the modelling framework IDEAS, discussed in the following section.

We describe two examples of collaborative learning. The Collaborative Learning Group on Sediment was a group of parties interested in the effects of and on fine sediment in the Motueka River. Fine sediment can be generated from land surface disturbance. Where this finer sediment then reaches the main river it can impact the instream biota. The extent and nature of this issue has been debated amongst a group of individuals from various stakeholder backgrounds, including a fishery manager, landowner, forestry manager, a member of a local Māori tribe and staff of government agencies.

The process was overseen by social scientists, interested in how the social interaction and learning process benefited the parties and informed and was informed by the biophysical research. Much of the benefit was derived from the process of assisting participants to learn of and see alternative perspectives on the same issue. The collaborative learning process allowed alternative views about the impacts of fine sediment loss to be shared among diverse stakeholders to build an agreed view of research priorities.

A second example concerns research motivating action to form a Catchment Landcare Group. ICM water quality research across the Motueka catchment showed that the Sherry River tributary had high levels of bacterial contamination

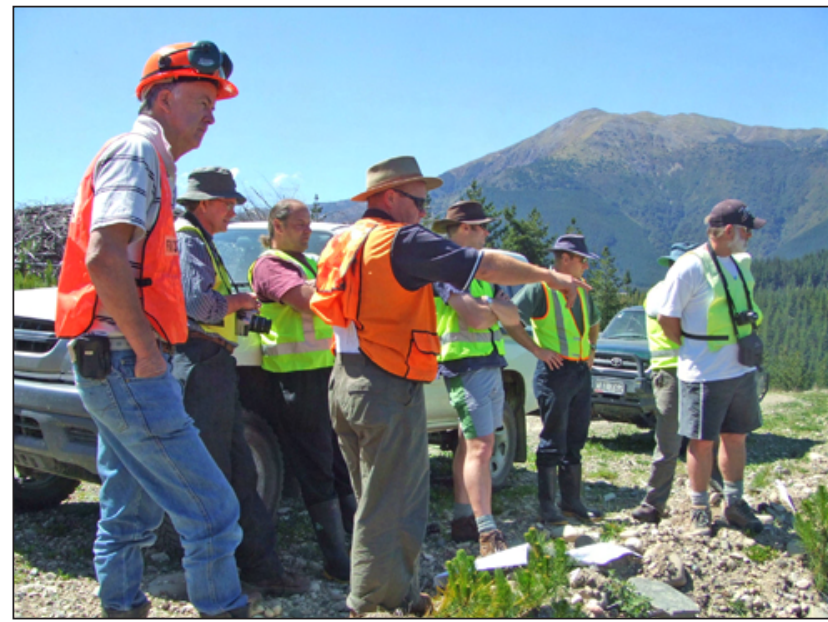

Figure 6

Sediment Learning Group exchanging views about sediment from forestry operations indicating that the river was unsafe for swimming in its lower reaches (Young et al. 2005). This information was presented to the ICM programme's Community Reference Group who passed this new knowledge through their community networks. ICM researchers were then invited to present the water quality results at a kitchen meeting of the eight major landowners in the catchment who were expressing concern at the high bacteria results, especially as they and their families enjoyed swimming in the river.

It was this one piece of information that galvanised the farmers into action - they wanted to know more! What was causing the problem and what could be done to fix it? They formed an ad hoc Landcare group and asked the scientists to get to the cause of the problem. In a collaborative exercise, researchers monitored water quality effects of cows crossing the river. Results showed E. coli levels reaching up to $50000 \mathrm{cfu} / 100 \mathrm{ml}$ in the Sherry when 246 cows crossed the river, effectively quadrupling the daily load of faecal bacteria in the river. Suspended solids and total nitrogen were also elevated by the herd crossing. The work also showed that cows are 50 times more likely to defecate in water than elsewhere on the raceway (Davies-Colley et al., 2004).

Importantly, the results were accepted by the farmers as they had asked the question, and were therefore an integral part of the research. The science showed that the solution to the problem was obvious - bridge the crossings - but expensive. The Council, having been party to the research, helped the landowners by rebating fees for bridge building consents. Now all 4 dairy crossings in the Sherry are bridged and $E$. coli levels have declined substantially. We also now have a community, the Sherry River Catchment Group, that is empowered and taking the next steps of farm environmental plans to show how to further improve water quality in their catchment.

Experience with groups such as the Sherry River Catchment Group and water user groups suggests the possibility of formal devolution of responsibility for environmental governance by catchment management groups.

Water user committees involving communities in water resource decision-making are already working successfully in the Motueka and adjacent river basins. These are established and supported by the Tasman District Council which has overall responsibility for water, land and coastal resource management. They advise on flow sharing during drought, suggest water allocation policy when plans are formulated, and guide water storage projects with full community representation.

They comprise representatives of, where appropriate, abstractive water users such as irrigators from discrete subcatchments or aquifers, local authority domestic water suppliers,

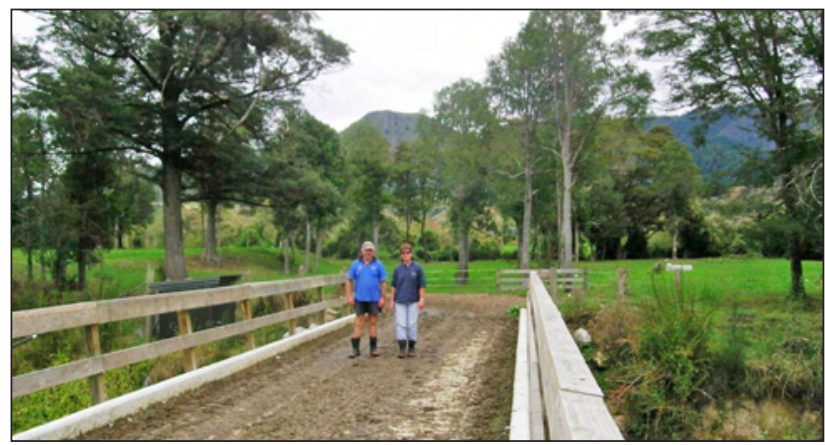

Figure 7

Dairy cows cross newly constructed farm bridge, Sherry River 
forestry and other land-use sectors, industry, local Māori tribes, biodiversity, recreation, fisheries and wildlife groups and sometimes even marine aquaculture. Each member must be mandated to represent their sector, which is not necessarily bound by the attempted consensus outcome, but generally most groups have realised their interest has greater likelihood of successful outcomes from active participation. A willingness to compromise, explore a variety of options and maintain good communication is essential for success.

All parties must have a good reason to be there - they must feel they are at least as likely, if not more likely, to get a better, more enduring or at least more cost effective result through dialogue than litigation or through political means.

Successful dialogue within these groups follows a similar pattern for each. The primary issue of concern must be scoped for example, critical water shortage during drought conditions, which may affect different interests by reducing security of supply for irrigators, restricting planting for foresters, or reducing fish populations for fishers. Relevant, impartial research knowledge is required such as into the hydrological regime, water requirements for particular crops, critical instream needs, and foreseeable water demand. Different parties scope and/or undertake these work programmes, preferably by drawing on funds provided by the parties in proportion to their interest or ability to contribute. It is crucial that the research objectives are agreed by all the parties and that the researchers or technical experts have their confidence.

The water user group can review the scientific or technical information, with one or more iterations until a consensus is reached on a minimum flow, rationing regime or size or location of water storage, for example. During the process, all parties learn about the needs of other sectors and develop personal relationships and understandings which assist in reaching a consensus. At all times, however, each sector representative must maintain a close liaison with their sector to ensure their mandate is maintained.

The process takes longer than a single party attempting to scope a proposal and then persuade others that this is the best option, but is more robust, enduring and likely to succeed. When decided, however, legal approvals have been granted in a matter of weeks without any opposition from any sectors, including environmental, recreational and local tribal interests. In contrast, some major applications for large-scale water harvest and irrigation schemes in other parts of New Zealand have proven highly divisive, with communities split and major and expensive opposition and litigation from alternative irrigation proponents, government agencies, environmental, recreational and Māori interests. Most parties soon realise that recourse to litigation is likely to result in considerably more expense without any real control over the outcome, which is decided by a third party such as a Court which is seldom better qualified to reach compromises than the parties would be themselves.

A similar approach is being considered for addressing diffuse source water quality runoff of nutrient or sediment from land uses. This approach would see landowners supported to take on a more devolved governance role, actively involved in setting acceptable water quality objectives for their sub-catchment and then working collectively with council support to achieve these, such as in the Sherry River case above.

Figure 8 modifies Arnstein's ladder of participation and shows that formalising this role would move such committees' role from an advisory one towards partnership or delegated power. At a sector workshop to discuss this and other water

\begin{tabular}{|c|c|}
\hline Citizen control & \multirow{3}{*}{$\begin{array}{l}\text { Degrees of } \\
\text { Citizen power }\end{array}$} \\
\hline Delegated power & \\
\hline Partnership & \\
\hline Advisory role & \multirow{2}{*}{$\begin{array}{l}\text { Degrees of } \\
\text { Counsel }\end{array}$} \\
\hline Consultation & \\
\hline Informing & \multirow{3}{*}{ Non-participation } \\
\hline Training & \\
\hline Manipulation & \\
\hline
\end{tabular}

Figure 8

Levels of governance, modified from Arnstein's ladder of participation (1969)

management reform proposals, there was support for this idea but with stronger support from conservation, Māori and government stakeholders than irrigation water users. The workshop considered they would need clear terms of reference, leadership and resourcing from the council, and good access to science (Sinner at al., 2006).

\section{IDEAS modelling across the quadruple bottom line}

Among the developing integrative tools for ICM and for managing HELP basins is scenario modelling. Models incorporating visualisation offer a powerful way to explore catchment futures. A challenge in the development of tools for ICM is ensuring they are fully utilised beyond the development phase by stakeholders. To meet this challenge IDEAS has both a social and technical stream of work associated with development.

The technical stream of IDEAS is a loosely linked set of biophysical and socio-economic models that may be applied at a range of scales, from local through to regional. However, it has particular strength at the catchment scale where bio-physical processes have strong spatial interactions. For example, in the Motueka catchment, there is strong interaction between nutrient export from agriculture and aquacultural productivity in Tasman Bay.

The social stream uses a participatory approach to ensure stakeholder knowledge is incorporated into the models, to set parameter thresholds and design scenarios, and to ensure users understand the inherent assumptions within the models used. Involving stakeholders creates a shared understanding of model operation and its limitations. The technical and social aspects together are called IDEAS - Integrated Dynamic Environmental Assessment System (Fig. 9).

Integration of biophysical with socio-economic models is difficult to achieve in a dynamic sense because bio-physical models at the catchment scale tend to be complex, requiring much input data and computer processing. Economic inputoutput tables have historically incorporated national or regional environmental outcomes through the use of biophysical coefficients. These coefficients represent flows of mass and energy through the economy by sector. However, at the catchment scale, the coefficients depend strongly on the spatial arrangement of land use or offshore coastal uses. For example, the total export of nitrogen from a dairy or sheep farm depends strongly on spatial factors like the proximity of stock to waterways, and the particular soil characteristics.

IDEAS enables the dynamic use of biophysical coefficients in socio-economic models using a lookup table relating biophysical coefficients to an appropriate land-use combination. From the lookup table, the socio-economic models access 
the appropriate coefficients according to the catchment communities' preferred land use scenario.

So far, both an IDEAS stakeholder group and the ICM Community Reference Group have identified and prioritised the types of issues they see for the catchment in future, and these form the basis for 6 Motueka catchment scenarios. These are:

(1) Pre-human

(2) Present land use

(3) Present land use with best management practice

(4) Very intensive agriculture

(5) Very intensive agriculture with best management practice

(6) Continued present growth until 2020.

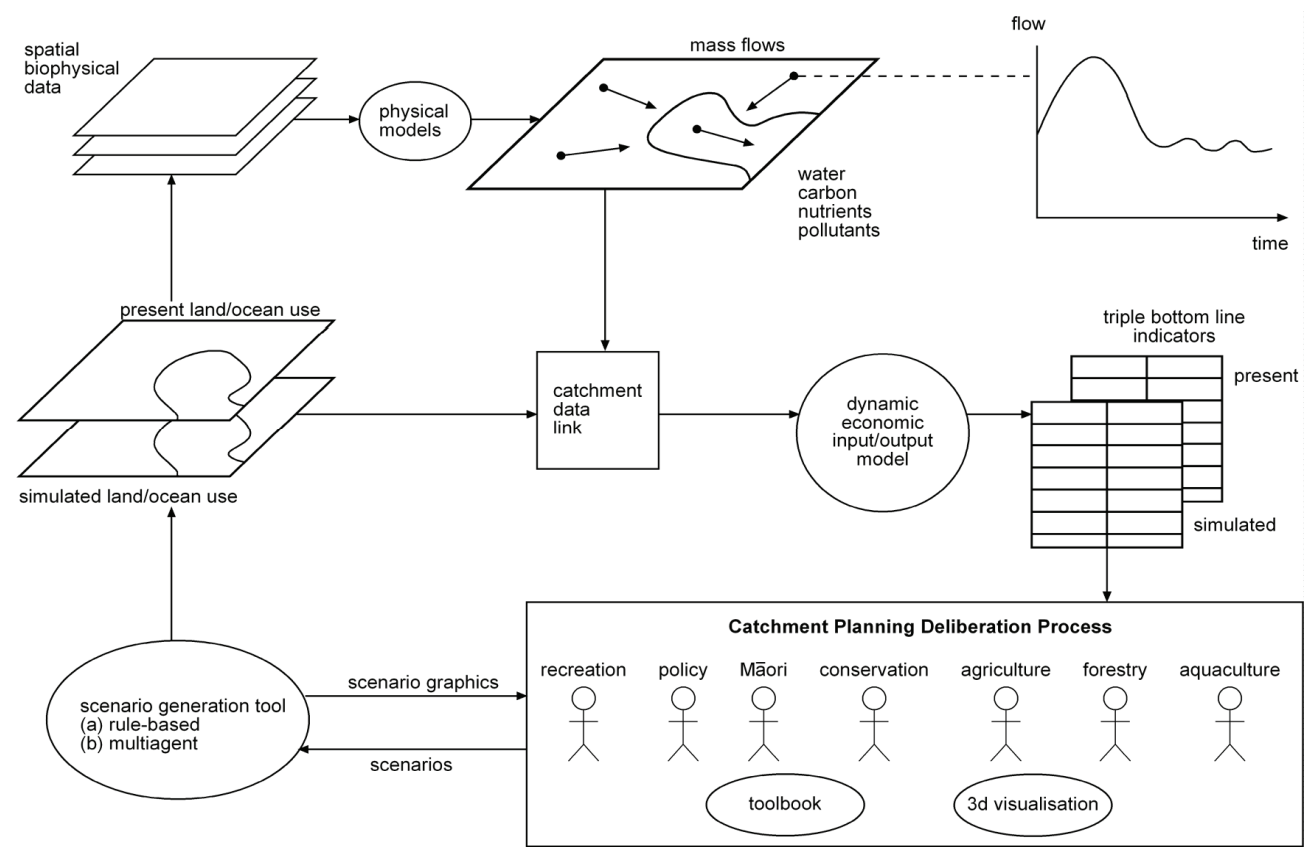

Figure 9

IDEAS assists catchment planning deliberation by assessing the environmental and socio-economic outcomes of catchment visions

Repetition Figure 10 summarises catchment environmental and socio-economic measures associated with Scenarios 1, 2, 4 and 6.

IDEAS is then applied to assess and compare the environmental and socio-economic impacts of their scenarios. Integration of environmental and socio-economic factors facilitates learning by stakeholders of the impact of their personal visions on other stakeholders.

While the socio-economic measures for Scenario (4) may be satisfactory (see Fig. 10), the environmental measures indicate problems with high nitrogen concentration in river water and lack of water for irrigation. And while increased nitrogen runoff creates more production from river plume mussel farms, the accompanying bacterial and sediment loads may restrict harvesting, reduce scallop production and encourage nuisance species.

IDEAS may be applied at a range of scales, from local through to regional. However, it has particular strength at the catchment scale where bio-physical processes have strong spatial interactions. For example, in the Motueka catchment, there is strong interaction between nitrogen runoff from agriculture and aquaculture productivity in Tasman Bay.

IDEAS does not provide a framework for conflict resolution, but it is a tool for helping people to understand the complex responses within a catchment system. Potential applications include local government strategic planning processes, and interactive scenario testing as an environmental education tool.

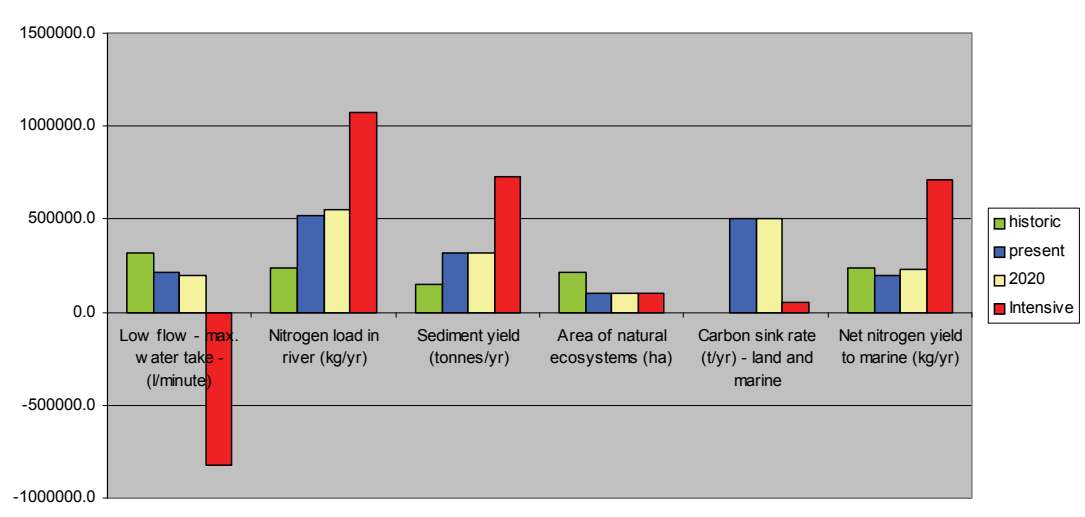

Socio-economic performance

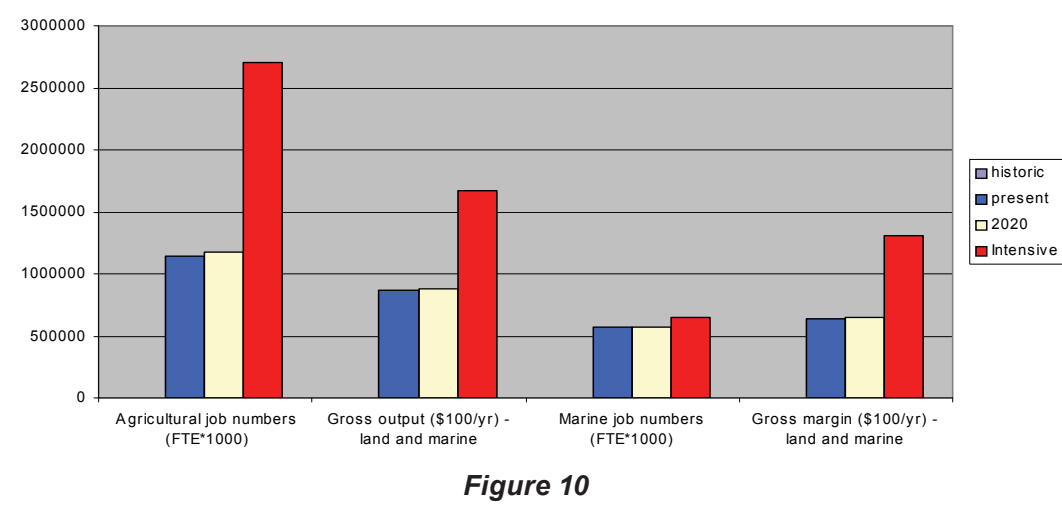

Environmental and socio-economic measures of pre-human, present, 2020 and intensive land use scenarios for the Motueka catchment from the IDEAS model

\section{Insights for HELP}

Integration is easy conceptually to understand but difficult to achieve in practice. This paper has described some collaborative 
learning and modelling tools being trialled in ICM research in New Zealand's Motueka catchment.

We see ICM as having two pillars, both of which need investment:

- Ecosystem resilience - understanding biophysical processes (e.g. hydrological) for resource management at catchment scale

- Community resilience - building community networks, informed by science, and implementing collaborative processes for governance.

A clear understanding of property rights in relation to water uses, social norms, technical understanding (and the limits to this) and acceptance of common objectives are all important success factors. Finding a common or critical matter of interest, such as the trout fishery in the case of the Motueka, can focus efforts and enable a wide range of options to be considered. This then enables groups which have realised the approach is successful to turn their attention to the next most important issue, such as marine productivity, or the sustainability trade-offs associated with forestry, agriculture or horticulture.

No single method can best describe the appropriate catchment scale for investigation or response. It depends on what is the main issue and objective. Some issues, like water quality effects of land use are manifested at a broad catchment scale, but are best addressed at a localised level. This can make effective 'bottom up' approaches difficult, as any benefits may appear too diffuse (to whole catchment water quality) while costs occur at the property scale. Other issues, like the effects of water abstraction on downstream water resources and interests must all be considered at the scale of the likely effect. Using catchments is essential for water based processes, but this does not always address the most important social questions, which often cross catchment boundaries.

There may be time lags between cause and effects such as the effects of afforestation on water yield or fine sediment generation. A precautionary approach is therefore recommended in allowing large scale change if ecosystem resilience is to be maintained.

Social research can assist with preparing for likely success and uptake of useful ideas. The community may become better able to articulate and consider possible futures with the benefit of biophysical and social research.

In the developed world, knowledge of basin processes is reasonable, if fragmented. Effort is now being put into research and implementation of knowledge management, integrated policy development, integrative evaluation, collaborative governance and social science. Work on developing both ecosystem resilience and community resilience is needed to make Integrated Catchment Management and the objectives of HELP a success in basins in both the developed and developing world.

\section{Acknowledgements}

We acknowledge the collaborative spirit and contributions of our research colleagues, sector, community and Council partners. Science contributions to this research have been funded by New Zealand's Foundation for Research, Science and Technology contract C09X0305. The two senior authors thank UNESCO and the South African organisers of the Southern HELP symposium for their support to present these ideas at the symposium in November 2007.

\section{References}

ALLEN WJ and KILVINGTON MJ (2005) A role for integrated and interdisciplinary science: Getting technical environmental information used in watershed and regional-scale decision making. Chapter 3 in Hatfield JL (ed.) The Farmers' Decision: Balancing Economic Successful Agriculture Production with Environmental Quality. Soil and Water Conservation Society. 45-61

ARNSTEIN SHERRY R (1969) A ladder of citizen participation. J. Am. Inst. Plann. 35 (4) 216-224.

BASHER LR (ed.) (2003) The Motueka and Riwaka Catchments. A technical report summarizing the present state of knowledge of the catchments, management issues and research needs for integrated catchment management. Landcare Research NZ, Lincoln. http:// icm.landcareresearch.co.nz/

BONELL M and ASKEW A (2000) The Design and Implementation Strategy of the Hydrology for Environment, Life and Policy (HELP) Initiative. HELP Task Force, United Nations Educational Scientific \& Cultural Organization, Paris, France.

BOWDEN WB and WILKINSON R (2000) Stakeholder Opinions Regarding Priority Research Issues for Land and Water Resource Management in the Motueka River Catchment, Tasman District. Landcare Research Report LC0001/07, Lincoln, NZ.

BOWDEN WB, FENEMOR AD and DEANS NA (2004) Integrated Water and Catchment Research for the Public Good: The Motueka River-Tasman Bay Initiative, New Zealand. Water Resour. Dev. 20 (3) 311-323.

DAVIES-COLLEY RJ, NAGELS JW, SMITH RA, YOUNG RG and PHILLIPS CJ (2004) Water quality impact of a dairy cow herd crossing a stream. NZ J. Mar. Freshwater Res.38 569-576.

DYMOND J, COLE A, DAVIE T, FENEMOR A and GIBBS M (2006) IDEAS - An Integrated Dynamic Environmental Assessment System for catchment planning. Landcare Research report. Available at http://icm.landcareresearch.co.nz/

FENEMOR AD, DAVIE T and MARKHAM S (2006) Hydrological information in Water Law and Policy: New Zealand's devolved approach to water management. Chapter 12 in J Wallace and P Wouters (eds.) Hydrology and Water Law - Bridging the Gap (IWA Publishing, London).

FORREST BM, GILLESPIE PA, CORNELISEN CD and ROGERS KM (2007) Multiple indicators reveal river plume influence on sediments and benthos in a New Zealand coastal embayment. NZ J. Mar. Freshwater Res. 41 13-24.

GUNDERSON L and HOLLING CS (2002) Panarchy: Understanding Transformations in Human and Natural Systems. Island Press, Washington.

KILVINGTON M and ALLEN WJ (2007) Evaluation of the Social Spaces of the Integrated Catchment Management (ICM) Research Programme. Landcare Research Report LC0607/183. Available at http://icm.landcareresearch.co.nz/

SINNER J, FENEMOR A and BAINES J (2006) A Case Study of Water Management in the Motueka Catchment: Responses to Water Allocation Reform Proposals. Joint Ecologic Foundation/Landcare Research report, available http://icm.landcareresearch.co.nz/. 25 pp.

WALKER B and SALT K (2006) Resilience Thinking. Island Press, Washington.

YOUNG RG, QUARTERMAN AJ, EYLES RF, SMITH RA and BOWDEN WB (2005) Water quality and thermal regime of the Motueka River: Influences of land cover, geology and position in the catchment. NZ J. Mar. Freshwater Res. 39 803-825. 